\title{
Wind offshore energy in the Northern Aegean Sea islanding region
}

\author{
Eleni Zafeiratou, Catalina Spataru \\ Energy Institute, University College London, \\ London, UK \\ e.zafeiratou@ucl.ac.uk, c.spataru@ucl.ac.uk
}

\author{
Raimund Bleischwitz \\ Institute for Sustainable Resources, University College \\ London, London, UK \\ r.bleischwitz@ucl.ac.uk
}

\begin{abstract}
The Greek state estimated a potential of 1,500 MW wind offshore capacity, which can be exploited by 2020 , while 943.15 MW are located in the Northern Aegean Sea islanding region. This study presents a techno-economic assessment of wind offshore energy in the Northern Aegean Sea. Different topologies are proposed, taking into account wind offshore and islands interconnections using HVDC and HVAC technology. Investment indicators are based on the expected power generated by the Weibull wind speed probability density function and the total investment cost required for wind offshore engineering. The results show that the two wind offshore farms can secure the complete electrification of the neighboring islands and supply approximately 3,379 GWh to the main consumption centers in northern and central Greece on an annual basis. A sensitivity analysis towards investment optimization has been performed, proposing different wind turbine technologies and interconnection scenarios.
\end{abstract}

Keywords-wind, offshore, energy, interconnections, HVDC, HDAC, islands

\section{INTRODUCTION}

\section{A. Background}

The first wind offshore test project in Europe was implemented in 1990, in Sweden, consisting of a single 220 $\mathrm{kW}$ wind turbine (W/T) [1]. Since then, wind offshore energy in Europe has gradually increasing, reaching in 2014 a share of $91 \%(8.05 \mathrm{GW})$ of the total capacity [2]. The leading countries for wind offshore are: UK, Germany, Denmark, The Netherlands, Belgium and Sweden. However, Norway, Portugal and Ireland have shown eagerness to expand their wind sector in offshore installations [3]. The most prominent wind offshore project in Europe currently is the North Sea grid interconnection with the potential to support $16.2 \mathrm{GW}$ of wind offshore energy in this area by 2017 [4]. Europe is targeting to reach $40 \mathrm{GW}$ of wind offshore capacity by 2020 and $150 \mathrm{GW}$ by 2030 [5].

In Greece, despite the high wind potential with wind speeds recorded in Aegean sea between 7 and $12 \mathrm{~m} / \mathrm{s}$ [6] alongside the coastline of $13.67 \mathrm{~km}$; very little efforts have been recorded in terms of implementation. Presently, 12 areas with $1.5 \mathrm{GW}$ potential, have been proposed by the Ministry of Environment, Energy and Climate Change as appropriate marine regions for wind offshore energy development. At the same time, applications of $2.44 \mathrm{GW}$ have been submitted to the regulatory authority for energy in Greece (RAE), in the Aegean Sea islanding region. The Greek state aimed to implement a number of them by the year of 2017, under the 2020 EU energy and climate change regulation framework [7]. Nonetheless, social, economic and technical challenges due to deep water depths have postponed their implementation.

\section{B. Future wind offshore projects in the Aegean Sea}

Two spots have been selected in the Aegean Sea noninterconnected islanding region, included in the 12 proposed areas by the Greek state, under the following criteria:

- $\quad$ High wind speed $>7 \mathrm{~m} / \mathrm{s}$

- Environmentally available zones

- Close distance from the shore

- Depth of seabed $<50 \mathrm{~m}$

The first wind offshore project, which has already received the energy production license, is located at the east side of Lemnos island (coordinates: $39^{\circ} 59^{\prime} \mathrm{N}, 25^{\circ} 29^{\prime} \mathrm{E}$ ), with total capacity $498.15 \mathrm{MW}$.

The second project, which is under evaluation to receive the license of production from RAE is located northern of Agios Efstratios (coordinates: $39^{\circ} 30^{\prime} \mathrm{N}, 25^{\circ} 06^{\prime} \mathrm{E}$ ), with $445 \mathrm{MW}$ capacity. Both sites belong to the prefecture of North Aegean.

The interconnection options for the two wind offshore sites suggest either autonomous submarine transmission lines to the shore or their inclusion in one of the existing HV interconnectors that will interconnect the islanding area.

\section{TECHNICAL CHARACTERISTICS OF OFFSHORE WIND FARMS}

\section{A. Wind turbine type}

\section{1) $W / T$ generator}

The predominant type of $\mathrm{W} / \mathrm{T}$ generator has asynchronous generators or high speed doubly-fed induction generators (DFIG). The DFIG operate with a wound rotor induction machine allowing variable wind speed generation [8]. A stator flux oriented vector control is used for the variable speed operation, the stator circuit is directly linked to the network and the rotor winding is connected to a three-phase converter 
[9], [10]. However, synchronous direct drive permanent magnet generator is becoming extensively used as it provides resilience compared to the high speed DFIG gear-driven systems [11]. The generator achieves increased power from the wind, with maximum efficiency under various load states, through robust control.

\section{2) W/T foundation structure}

The main criterion of diversification among W/Ts foundation applications is the water depth as presented in TABLE I. The principal foundation type is monopile accounting for the $75 \%$ of the current installed offshore $\mathrm{W} / \mathrm{T}$ as it can be applied to different water depths. Monopile is followed by gravity foundation (21\%), Jacket (2\%) and tripod $(2 \%)$ structures [1], as illustrated in Fig. 1. Gravity counts applications usually in shallow waters while Jacket and tripod are preferred in locations with submarine water elevation ranging between -20 and $-50 \mathrm{~m}$. Floating $\mathrm{W} / \mathrm{T}$ constitutes a new, emerging technology which increases shares in the W/T offshore market, as it allows the installation of W/T in depths more than $50 \mathrm{~m}$, while expanding the possibilities of wind offshore implementation to distant sites with high wind speed records [12], [13].

\section{B. HVAC \& HVDC submarine technology}

High voltage alternative current (HVAC) is used for wind offshore projects and islands interconnection, mainly in close distances from the shore, as AC cables limit the transmission distance for submarine cables to the break-even-length of 50 $\mathrm{km} \mathrm{[14],} \mathrm{[15].} \mathrm{AC} \mathrm{connections} \mathrm{show} \mathrm{higher} \mathrm{levels} \mathrm{of}$ dependability compared to HVDC technology, as they present $30 \%$ less frequency in the events of 'expectable inability to supplied power' [16]. The AC interconnection of an offshore wind farm consists of the submarine transmission cables, two transformers offshore and onshore, reactive power compensators and the offshore platform. Nowadays, submarine cables use mostly extruded polymer (XLPE) insulation with copper or aluminum conductors, while threecore AC cables are chosen for submarine applications [17]. The main shortcoming of AC technology is the capacitive charging current which decreases cables' transmission efficiency; however this could be relatively alleviated by positioning shunt reactors, at the end of the cable [18].

TABLE I. W/T FOUNDATION BASED ON WATER DEPTH

\begin{tabular}{|c|c|c|c|c|c|c|}
\hline \multirow{2}{*}{$\begin{array}{l}\text { W/T } \\
\text { Foundation }\end{array}$} & \multicolumn{6}{|c|}{ Water Depth } \\
\hline & $1 \mathrm{~m}$ & $10 m$ & $20 m$ & $30 m$ & $40 m$ & $>50 m$ \\
\hline Gravity base & $\checkmark$ & $\checkmark$ & $\checkmark$ & & & \\
\hline Monopile & $\checkmark$ & $\checkmark$ & $\checkmark$ & $\checkmark$ & & \\
\hline $\begin{array}{ll}\text { Tripod } & \& \\
\text { Jacket } & \\
\end{array}$ & & & $\sqrt{ }$ & $\checkmark$ & $\checkmark$ & $\checkmark$ \\
\hline Floating & & & & & & $\sqrt{ }$ \\
\hline
\end{tabular}

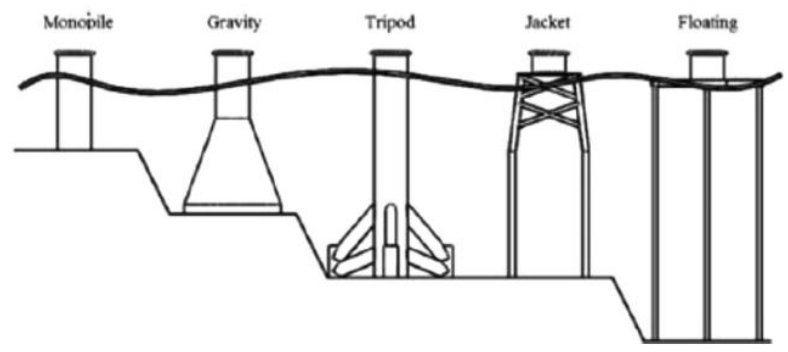

Fig. 1. Types of offshore W/T foundations [11]
High voltage direct current (HVDC), is tending to become worldwide the most reliable technology in wind offshore interconnections. In contrast with $\mathrm{AC}, \mathrm{DC}$ technology is not distressed by cable charging currents and allows mass power transmission through long distances [14]. Mainly voltagesource converter (VSC) HVDC technology allows rapid control over active and reactive power on the whole operation scale through the AC-DC-AC converters able to meet and exceed all interconnection voltage/frequency control requirements. Moreover, HVDC can be connected to weaker power systems compared to $\mathrm{AC}$ interconnections allowing larger wind farm integration [19], [20].

The main weakness of DC cables is related to restricted redundancy. That means that an outage in one pole leads to the total loss of the VSC-HVDC link. For that reason, the bipolar configuration is more apposite for island and wind offshore interconnectors, since as merely $50 \%$ of the transmission capacity could be lost in case of damage and set off to $\mathrm{N}-1$ conditions [21].

\section{OFFSHORE WIND FARMS CONFIGURATION AND INTERCONNECTION}

\section{A. Lemnos offshore wind farm}

Two options have been assessed for this wind farm: the base case, through a direct HVDC transmission line to northern Greece, dependent on a private investment or following the national strategy to interconnect the non-interconnected island of Lemnos.

The first option is proposed to be implemented by using voltage source converters with DC cables. The total capacity of $498 \mathrm{MW}$, consisting of $81 \mathrm{~W} / \mathrm{T}$, is located approximately $109 \mathrm{~km}$ away from the nearest available onshore point in the mainland. The connection point was selected to be close to the existing HVAC $400 \mathrm{kV}$ transmission line, in the wider region of Xanthi, in Northern Greece. The minimum distance from Lemnos is estimated to $1.5 \mathrm{~km}$. The relatively close distance to the island allows the converters installation onshore, while reducing costs. The average water depth in the Lemnos offshore site was estimated by collecting the relevant data for 23 points in the site from the US National Oceanic and Atmospheric Administration, showing an average water depth of $27 \mathrm{~m}$ within a range between $9 \mathrm{~m}$ and $37 \mathrm{~m}$. Monopile foundation is recommended to support $\mathrm{W} / \mathrm{T}$ in various water depths for this site.

The wind generator selected is a commercially available 6.15 MW unit, incorporating doubly fed induction generators. The nominal operating frequency of the grid is $50 \mathrm{~Hz}$, and threestage planetary gearboxes with ratio 1:97 are used.

The offshore electrical network comprises of nine generator groups. Each group consists of nine generators connected via string configurations. These groups form the wider group of $498 \mathrm{MW}$, connected with collector substations including the transformers of $33 / 300 \mathrm{kV}$. The VSC transmission system is split in the grid side VSC and in the wind farm side VSC. The purpose of the wind farm VSC is to collect energy from the local wind farm and concurrently control its $\mathrm{AC}$ voltage and frequency. The grid side VSC is used to control the DC 
voltage and guarantee that the energy collected from the wind farm VSC is transmitted to the onshore grid [22].

The VSC converter is connected to a common DC bus consisting of two $\pm 150 \mathrm{kV}$ VSC-HVDC links, each of them rated $\approx 250 \mathrm{MW}$ operating at the same DC voltage in a parallel connection. The double wiring is proposed in order to enhance reliability to the system in case one of the cables in lost or damaged, however a common $400 \mathrm{kV} 500 \mathrm{MW}$ line is also examined in the economic analysis. The DC voltage is maintained at the nominal level $(150 \mathrm{kV})$ by the single VSC inverter located onshore. At the onshore connection point the transformers will elevate voltage to $400 \mathrm{kV}$.

\section{B. Agios Efstratios offshore wind farm}

Agios Efstratios wind farm consists of $89 \mathrm{~W} / \mathrm{Ts}$ of $5 \mathrm{MW}$, split in 25 groups. The main volume of $\mathrm{W} / \mathrm{Ts}$ is located with a minimum distance of $3.1 \mathrm{~km}$. The mean water depth following an analysis of 39 points was $26.7 \mathrm{~m}$. However, the range fluctuates from 16 to $49 \mathrm{~m}$ [23], leading to the decision to apply Jacket foundation to $35 \mathrm{~W} / \mathrm{Ts}$ at the north east part of the site while the remaining 54 will be founded with monopile constructions. The technology proposed for this project assuming a direct line of $158 \mathrm{~km}$ to North Greece is VSC HVDC. A commercially available $5 \mathrm{MW}$ wind turbine with a synchronous generator with permanent magnets has been selected. Agios Efstratios wind project follows the same interconnection topology with Lemnos site.

\section{Interconnection alternatives}

\section{1) Wind offshore via islands interconnection}

The Greek national strategy suggests the interconnection of Lesvos and Chios islands with Evia island and central Greece. Following this, the interconnection of Lemnos from Lesvos through an intermediate substation in Agios Efstratios island (Fig. 2). This plan splits the $120 \mathrm{~km} \mathrm{AC} \mathrm{cable} \mathrm{of} \mathrm{nominal}$ capacity $2 * 150 \mathrm{kV}$ from Lesvos to Lemnos in: $80 \mathrm{~km}$ between Lemnos and Lesvos and $40 \mathrm{~km}$ between Agios Efstratios and Lemnos. The last stage, suggests the expansion of the interconnection to Northern Greece and specifically to the 400 $\mathrm{kV}$ line through the substation located in the area of Philippi with transmission capacity equal to $500 \mathrm{MW}$. The link to northern Greece is considered essential, since the interconnection through Larimna in central Greece does not allow efficient power load transmission to the northern consumption centers.

Wind onshore expansion in the southern part of Aegean Sea, could pose additional threats to the southern power system's stability. Therefore, the northern islands interconnection could facilitate the interconnection of Agios Efstratios power network with the offshore wind project, through HVAC 150 $\mathrm{kV}$ transmission lines to Lemnos island and Lemnos wind offshore to northern Greece. This configuration could integrate offshore wind projects alongside islands interconnection in order to improve maritime spatial planning in the Aegean Sea and serve demand loads to the consumption centers in the mainland. Economic benefits could arise from this joint venture of public and private sector by sharing capital costs for the submarine network infrastructure.

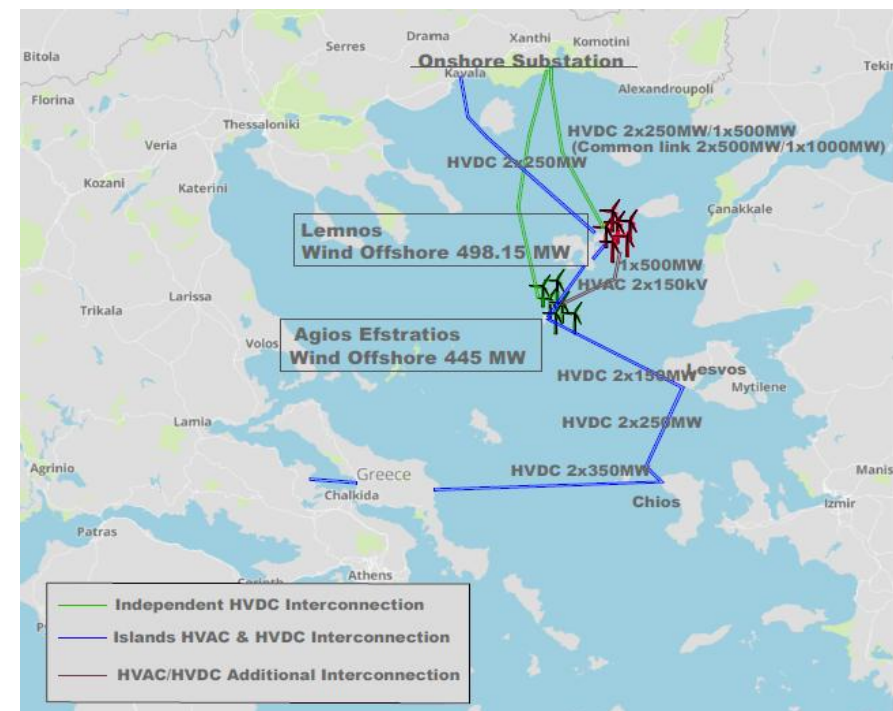

Fig. 2. Interconnection plans for wind offshore farms in the Northern Aegean Sea islanding region

This interconnection plan needs improvements such as: (a) the enhancement of the Philippi substation with additional transformers (b) the overhead transmission lines enhancement of $400 \mathrm{kV}$ in the mainland for transmitting additional loads from the offshore wind farms (c) the enhancement of the DC interconnection with at least one or two cables of $500 \mathrm{MW}$ nominal capacity, depending on wind onshore expansion. Furthermore, the power flow, voltage stability as well as the power system analysis following the integration of high intermittent wind power loads to the national grid is required.

\section{2) Lemnos and Agios Efstratios wind offshore connection}

Other topologies in order to increase reliability and controllability introduce the enhancement of the interconnection between the two wind farms by installing a third DC cable, linking the DC cables of the two wind projects. This option will increase the reliability of the system and in case one of the two DC links is lost, an amount of load from the two wind farms will continue to be supplied to the national grid. Additional costs include the extra DC circuit breakers and the HVDC cable linking the two networks. The same concept could be applied with an AC auxiliary transmission line linking the two AC $150 \mathrm{kV}$ cables.

A second proposal in order to reduce costs of the long submarine transmission line recommends switching from the multi-terminal option to a main DC link transmitting power from the two wind projects to the shore. This option requires enhancement of the main transmission capacity of the interconnection from $500 \mathrm{MW}$ to $1000 \mathrm{MW}$. This scenario could be realized also with an AC transmission link to common VSCs in Lemnos site.

\section{POWER GENERATION}

Power generation was estimated for the wind sites considering wind data from 1999 to 2004 [24]. MATLAB has been used for the modeling exercise. The Weibull wind speed distribution equation was used to identify the probability of wind speed (V) being observed within the range of $\mathrm{V}+\mathrm{dV} / 2$ and $\mathrm{V}-\mathrm{dV} / 2$ in the given dataset. Factors $\mathrm{k}$ (the dimensionless Weibull shape parameter) and c [the Weibull scale parameter 
$(\mathrm{m} / \mathrm{s})$ ] have been calculated for each project. Following this methodology, the average power output $\mathrm{P}_{\text {avg }}$ per wind turbine and the capacity factor $C_{f}$ have been estimated according to the following mathematical formulation.

$$
\mathrm{f}(\mathrm{V}) d V=\frac{\mathrm{k}}{\mathrm{c}}\left(\frac{\mathrm{V}}{\mathrm{c}}\right)^{\mathrm{k}-1} \mathrm{e}^{-\left(\frac{\mathrm{V}}{\mathrm{c}}\right)^{\mathrm{k}}} d V
$$

Where $\mathrm{k} \& \mathrm{c}$ are: $\quad \mathrm{k}=\frac{\sigma}{\mathrm{v}_{\mu}}(-1,086) \quad(1 \leq \mathrm{k} \leq 10)$

$$
\mathrm{c}=\frac{\mathrm{v}_{\mu}}{\Gamma\left(1+\frac{1}{\mathrm{k}}\right)}
$$

$\mathrm{V}_{\mu}$ (mean wind speed), $\sigma$ (standard deviation) and $\Gamma$ distribution are calculated as:

$$
\begin{gathered}
\mathrm{v}_{\mu}=\frac{1}{\mathrm{n}} \sum_{\mathrm{i}=1}^{\mathrm{n}} \mathrm{v}_{\mathrm{i}} \\
\sigma=\sqrt{\frac{1}{\mathrm{n}-1} \sum_{\mathrm{i}=1}^{\mathrm{n}}\left(\mathrm{v}_{\mathrm{i}}-\mathrm{v}_{\mu}\right)^{2}} \\
\Gamma=\int_{0}^{\infty} \mathrm{e}^{-\mathrm{u}} \mathrm{u}^{\mathrm{x}-1} \mathrm{du}
\end{gathered}
$$

Resources considered in this study reflect $10 \mathrm{~m}$ measurements. Extrapolation to the relevant hub height as indicated in TABLE II has been applied according to (7). Roughness in the sea surface is diminished to class 0 , considering the roughness length $\mathrm{z}_{0}$ equal to $2 * 10^{-4}$ [25].

$$
\mathrm{v}_{2}=\mathrm{v}_{1} *\left(\frac{\ln \left(\mathrm{z}_{2} / \mathrm{z}_{0}\right)}{\ln \left(\mathrm{z}_{1} / \mathrm{z}_{0}\right)}\right)
$$

The actual W/T power output considering the following: $\mathrm{V}_{\mathrm{c}}$ (cut-in wind speed), $\mathrm{V}_{\mathrm{f}}$ (cut-out wind speed), $\mathrm{V}_{\mathrm{r}}$ (rated wind speed), $V_{m}$ (the average of $V_{c}$ and $V_{r}$ ) and $P_{R}$ (rated power), is verified by the $\mathrm{W} / \mathrm{T}$ performance curve $(8)$.

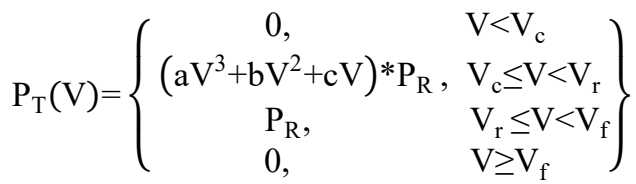

Where $a, b$ and $c$ are the regression indicators of the $\mathrm{W} / \mathrm{T}$

\begin{tabular}{|c|c|c|c|c|c|c|c|c|}
\hline \multirow[b]{2}{*}{$\begin{array}{l}\text { Capa } \\
\text { city } \\
\text { (MW) }\end{array}$} & \multicolumn{8}{|c|}{ W/T Specifications } \\
\hline & $\begin{array}{l}V_{c} \\
(\mathrm{~m} / \mathrm{s})\end{array}$ & $\begin{array}{l}V_{f} \\
(\boldsymbol{m} / \mathrm{s})\end{array}$ & $\begin{array}{l}\begin{array}{l}V_{r} \\
(m / s)\end{array} \\
\end{array}$ & $\overline{P_{R}}$ & $\begin{array}{l}\text { Hub } \\
\text { Heig- } \\
\text { ht } \\
(\mathrm{m})\end{array}$ & $\begin{array}{l}\text { Rotor } \\
\text { dia- } \\
\text { meter } \\
(\mathrm{m})\end{array}$ & $\begin{array}{l}\text { Swept } \\
\text { Area } \\
\left(\mathrm{m}^{2}\right)\end{array}$ & Generator \\
\hline 6.15 & 3.5 & 30 & 14 & 6,150 & 112 & 126 & 12,469 & $\begin{array}{l}\text { Double-fed- } \\
\text { induction } \\
\text { generator }\end{array}$ \\
\hline 5 & 3 & 30 & 10 & 5,000 & 94 & 132 & 13,685 & $\begin{array}{l}\text { Sychronous } \\
\text { with } \\
\text { permanent } \\
\text { magnets }\end{array}$ \\
\hline 8 & 4 & 25 & 11 & 8,000 & 105 & 164 & 21,124 & $\begin{array}{l}\text { Medium } \\
\text { Speed } \\
\text { Permanent } \\
\text { Generator }\end{array}$ \\
\hline
\end{tabular}
performance curve:

$$
\begin{aligned}
& a+b^{*} V_{c} * c^{*} V_{c}{ }^{2}=0 \\
& a+b * V_{r} * c^{*} V_{r}{ }^{2}=P_{R} \\
& a+b * V_{m} * c * V_{m}{ }^{2}=P_{R} *\left(\frac{V_{m}{ }^{3}}{V_{r}{ }^{3}}\right)
\end{aligned}
$$

TABLE II. WIND TURBINES CHARACTERISTICS
Dividing the actual energy output of a wind turbine $\left(\mathrm{P}_{\mathrm{T}}\right)$ by the theoretical wind energy yield $\left(\mathrm{P}_{\mathrm{R}}\right)$ and multiplying it with the the theoretical maximum coefficient (16/27) of power for a W/T known as Betz limit (Ragheb, 2014), the capacity factor is described as:

$$
\mathrm{C}_{\mathrm{f}}=\frac{\mathrm{P}_{\mathrm{T}}}{\mathrm{P}_{\mathrm{R}}} * \text { Betz limit }
$$

Annual power generation for each site was estimated as:

$$
P_{\text {avg }}=C_{f} * h * P_{n o m} * N_{w / T} / 1000
$$

Transmission losses are estimated to $1.5 \%$ of the annual energy output while VSC losses $4.5 \%$ per annum, including variable and constant losses. Additional losses considering the power generation of the wind farm such as: W/T availability and maintenance losses (3\%), losses due to wind speed hysteresis, balance of plan availability, turbine performance and environmental losses $(1.5 \%)$ have been incorporated in the analysis. Icing and height altitude is not included in the losses

\begin{tabular}{|c|c|c|c|c|c|c|c|}
\hline \multirow{2}{*}{$\begin{array}{l}\text { Wind } \\
\text { Offshore } \\
\text { Site }\end{array}$} & \multicolumn{7}{|c|}{ Wind Project Characteristics } \\
\hline & $k$ & $\begin{array}{l}c \\
(m / s)\end{array}$ & $\begin{array}{l}V m \\
(m / s)\end{array}$ & $\begin{array}{l}P_{T} \\
(M W)\end{array}$ & $\begin{array}{l}C f \\
(\%)\end{array}$ & $\begin{array}{l}P_{\text {avg }} \\
(G W h / \\
\text { year/ } \\
\text { W/T }) \\
\end{array}$ & $\begin{array}{l}\text { Total P Pvg } \\
(\text { GWh }) / \\
\text { Yearl } \\
\text { Site })\end{array}$ \\
\hline Lemnos & 1.7 & 9.24 & 8.24 & 4.64 & 44.7 & 24.08 & $1,745.7$ \\
\hline $\begin{array}{l}\text { Agios } \\
\text { Efstratios }\end{array}$ & 1.9 & 9.91 & 8.79 & 2.54 & 30.2 & 13.21 & $1,052.3$ \\
\hline
\end{tabular}
factors for wind offshore.

Fig. 3 depicts the Weibull distribution in accordance with the wind measurement histogram for each site. Weibull distribution tends to coincide with statistics, validating the precision of this method and eliminating uncertainties in wind speed measurements.
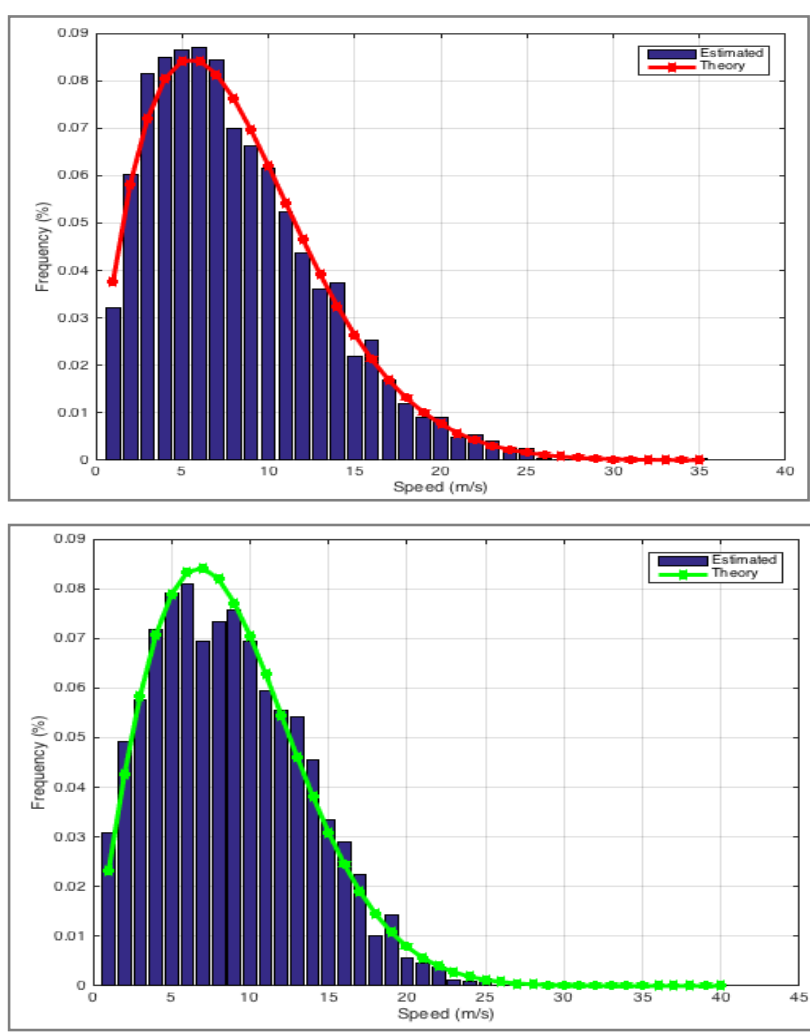

Fig. 3. Wind speed measurement data from 1999-2004 and Weibull Distribution for (a) Lemnos (red), (b) Agios Efstratios (green)

TABLE III. WEIBULL ANALYSIS \& ANNUAL POWER OUTPUT 
TABLE III presents results from the wind data analysis. High efficiency factors are identified due to the high wind potential recorded in the Aegean Sea islanding area. Although Agios Efstratios records the highest average wind speed, it presents relatively lower efficiency. This is attributed to the $5 \mathrm{MW}$ $\mathrm{W} / \mathrm{T}$ power curve presenting a rated power at $10 \mathrm{~m} / \mathrm{s}$ which affects the regression indicators $(a, b, c)$ and consequently impacts the $\mathrm{W} / \mathrm{T}$ performance between the $\mathrm{V}_{\mathrm{c}}$ and the $\mathrm{V}_{\mathrm{r}}$. Whereas the $6.15 \mathrm{~W} / \mathrm{T}$ possess a higher rated wind speed (14 $\mathrm{m} / \mathrm{s}$ ) allowing the wind turbine to expand its optimum wind speed range.

Assuming the replacement of the $5 \mathrm{MW} \mathrm{W/T}$ with two different $\mathrm{W} / \mathrm{T}$ generators: (a) the latest $\mathrm{W} / \mathrm{T}$ model $8 \mathrm{MW}$ capacity which became commercially available in 2014 (b) the 6.15 MW model applied also in Lemnos sites, we observed the following differences:

- Selection (a) leads to a slight improvement in energy efficiency reaching $32.55 \%$ per $\mathrm{W} / \mathrm{T}$.

- Option (b) increases $\mathrm{C}_{\mathrm{f}}$ to $46.83 \%$ reflecting the effiecient performance of the wind turbine in higher rated wind speeds.

The total power generation of the two wind offshore farms is estimated to cover energy requirements for approximately 850 thousand households assuming an average power consumption of $3.98 \mathrm{MWh}$ per household [27]. This will lead to a gradual decomission of a number of old and environmentally pollutant lignite power stations of total capacity $4.44 \mathrm{GW}$ operating in North Greece.

\section{COST ESTIMATION}

\section{A. Mathematical Formulation}

Investment costs for wind offshore are estimated to be from $18 \%$ to $66 \%$ higher than the wind onshore installations, while operating expenses might increase up to three times [1]. Junginger estimates cost reductions for 2020 by almost $40 \%$, compared to 2005 values [28]. A feasibility analysis of wind offshore projects in the Aegean Sea islanding region has been conducted in MATLAB according to the following methodology.

Assuming an investment cost equal with $\mathrm{C}$, this can be split among the investor, the bank and the state as follow:

$$
\mathrm{C}=\mathrm{e}^{*} \mathrm{C}+\mathrm{j}^{*} \mathrm{C}+\mathrm{s}^{*} \mathrm{C}
$$

Where e $(\%), \mathrm{j}(\%)$ and $\mathrm{s}(\%)$ correspond to the participation percentages between the three parties respectively.

The annual revenues before taxation are described by the following equation:

$$
\mathrm{R}_{\mathrm{t}}=\mathrm{P}_{\mathrm{t}} * \mathrm{Po}^{*}(1+\mathrm{i})^{\mathrm{t}}
$$

Where, $\mathrm{P}$ is the annual power generated, $\mathrm{Po}$ is the power price per $\mathrm{kWh}$ and $\mathrm{i}$ is the average inflation factor for Greece per year, $t$ corresponds to the year of operation.

The installments $\left(\mathrm{I}_{\mathrm{t}}\right)$ are distributed equally during the payback period of this project as described below:

$$
\mathrm{I}_{\mathrm{t}}=\left(\mathrm{L}_{\mathrm{i}}+\frac{\mathrm{L}_{\mathrm{i}}}{\left(1+\mathrm{L}_{\mathrm{i}}\right)^{\mathrm{n}}-1}\right) * \mathrm{j} * \mathrm{C}
$$

Where $L_{i}$ is the loan interest and $n$ is the installment of the loan.
The annual cash flow following taxation according to the Greek tax system is:

$$
\mathrm{Ncf}_{\mathrm{t}}=\left(\mathrm{R}_{\mathrm{t}}-\mathrm{O} \& \mathrm{M}_{\mathrm{t}}-\mathrm{I}_{\mathrm{t}}\right)^{*} \mathrm{Tax}
$$

Where O\&M are the annual operation and maintenance expenses and Tax is considered the annual tax rate.

Key indicators as the net present value (NPV) presented in (18) and the internal rate of return (IRR) factors have been identified in order to assess the viability and profitability of the projects. IRR is the interest rate which makes the NPV equal to zero.

$$
\mathrm{NPV}=\sum_{\mathrm{t}=1}^{\mathrm{t}}\left[\mathrm{Ncf}_{\mathrm{t}} /(1+\mathrm{IRR})^{\mathrm{t}}\right]-\mathrm{C}
$$

Where Ncf symbolizes the cash flows of the project for $t$ periods (years).

Also, the IEA method has been adopted (19) for estimating levelized costs of energy (LCOE). LCOE is the total of the discounted costs through the project's lifetime, allotted across the discounted parts of power produced taking into account only the equity capital costs. This provides a more holistic overview, of a wind offshore investment over its life cycle, per unit of power generated, expressed in $€ / M W h$ (IEA, 2011).

$$
\mathrm{LCOE}=\frac{\mathrm{e}^{*} \mathrm{C}+\sum_{1}^{\mathrm{t}} \frac{\left.(1-\mathrm{Tax}) *\left(0 \& \mathrm{M}_{\mathrm{t}}+\mathrm{F}_{\mathrm{t}}+\mathrm{D}_{\mathrm{t}}\right)-\mathrm{Tax}_{(\mathrm{Lit}}+\mathrm{Dep}_{\mathrm{t}}\right)}{(1+\mathrm{IRR} \mathrm{e})^{\mathrm{t}}}}{\sum_{1}^{\mathrm{t}} \frac{\mathrm{P}_{\mathrm{t}}(1-\mathrm{Tax})}{(1+\mathrm{IRR})^{\mathrm{t}}}}
$$

Where $r_{e}$ is the equity IRR, $F_{t}$ is the fuel cost (W/T don't include fuel costs only in the transportation stage \&

\begin{tabular}{|c|c|c|}
\hline \multicolumn{2}{|c|}{ Economic Indicator } & Assumptions \\
\hline Period of time & $(\mathrm{t})$ & 20 years \\
\hline Interest Rate & $\left(\mathrm{L}_{\mathrm{i}}\right)$ & $5 \%$ \\
\hline Tax rate & $(\operatorname{Tax})$ & 26\% (Data Source: Hellenic Republic, 2013) \\
\hline Payback Period & & 15 years \\
\hline Grace Period & & 2 years \\
\hline Financing scheme & & $30 \%$ capital costs and $70 \%$ loan ( $0 \%$ state $)$ \\
\hline Inflation Greek & (i) & $1 \%$ \\
\hline Inflation EU & $\left(\mathrm{i}_{\mathrm{eu}}\right)$ & $3 \%$ \\
\hline Depreciation & (Dep) & $\begin{array}{l}10 \% \text { per year for Engines and Electronic } \\
\text { Equipment } \\
4 \% \text { per year for Civil Constructions (Data } \\
\text { Source: Hellenic Republic, 2013) }\end{array}$ \\
\hline Power Price & (Po) & $\begin{array}{c}\text { 105€/MWh (Data source: Hellenic Republic, } \\
\text { 2014a) }\end{array}$ \\
\hline
\end{tabular}
construction phase for machinery), $D_{t}$ is the decommission cost and Dep $p_{t}$ is the depreciation of year $t$.

TABLE IV summarizes the economic assumptions included in the feasibility analysis.

TABLE IV. ECONOMIC ANALYSIS ASSUMPTIONS

\section{B. Costs}

Investment costs for the wind offshore project consist of the $\mathrm{W} / \mathrm{Ts}$, the support structure sand the grid infrastructure as presented analytically in TABLE V. Installation costs are estimated to be $20-25 \%$ of the procurement costs for terrestrial infrastructure and $35-40 \%$ for submarine [32].

Operation \& maintenance (O\&M), insurance and decommission costs dominate the efficiency of the project, presenting increased rates due to the volatility of offshore engineering. 
Foundation cost is a basic aspect of the project accounting usually for more than $13 \%$ of the total budget [1]. According to the W/T specifications and position, the relevant costs have been estimated on a per MW basis based on the following equations configured by literature review analysis [33] and indexed to 2020 values. Equations (20) and (22) show that costs are subject to the water depth $\left(D_{w}\right)$. It is evident that only gravity structures are affected by the distance from the shore $\left(\mathrm{d}_{\text {shore }}\right)$. Floating $\mathrm{W} / \mathrm{T}$ s cannot at the moment be described by an equation as they demonstrate an emerging technology with negligible applications. An average cost of 0.968 million Euros per MW has been assumed on 2020 values [33].

$$
\begin{aligned}
& \mathrm{C}_{\text {monopile }}=423,127 \mathrm{e}^{(0.0182 \mathrm{Dw})} \\
& \mathrm{C}_{\text {gravity }}=358,633+244.93 \mathrm{~d}_{\text {shore }} \\
& \mathrm{C}_{\text {Jacket }}=15,128 \mathrm{D}_{\mathrm{w}}+325,670
\end{aligned}
$$

TABLE V. COSTS BREAKDOWN [17], [32], [33]

\begin{tabular}{|l|r|r|}
\hline \multirow{2}{*}{$\begin{array}{l}\text { Element of the Wind Offshore } \\
\text { Project }\end{array}$} & \multicolumn{2}{|c|}{ Cost (projected in 2020) } \\
\cline { 2 - 3 } & \multicolumn{1}{|l|}{ Value } & \multicolumn{1}{l|}{ Rate } \\
\hline W/T & 1.0 & $\mathrm{M} € / \mathrm{MW}$ \\
\hline HVDC submarine $250 \mathrm{MW}$ & 0.45 & $\mathrm{M} € / \mathrm{km}$ \\
\hline HVDC submarine $500 \mathrm{MW}$ & 1.38 & $\mathrm{M} € / \mathrm{km}$ \\
\hline HVDC submarine $1000 \mathrm{MW}$ & 0.35 & $\mathrm{M} / \mathrm{km}$ \\
\hline HVAC submarine $33 \mathrm{kV}$ & 0.6 & $\mathrm{M} € / \mathrm{km}$ \\
\hline HVAC submarine $150 \mathrm{kV}$ & 0.13 & $\mathrm{M} € / \mathrm{km}$ \\
\hline HVAC overhead $150 \mathrm{kV}$ & 0.35 & $\mathrm{M} € / \mathrm{km}$ \\
\hline HVAC underground $150 \mathrm{kV}$ & 2.5 & $\mathrm{M} €$ \\
\hline Transformer 33/300kV & 75 & $\mathrm{M} €$ \\
\hline Voltage Source Converter 300kV & 6.5 & $\mathrm{M} €$ \\
\hline HVAC GIS Switch Gear 400kV & 4.5 & $\mathrm{M} €$ \\
\hline HVAC GIS Switch Gear $150 \mathrm{kV}$ & 10.7 & $\mathrm{M} €$ \\
\hline $\begin{array}{l}\text { Offshore Substation Collector (Jacket } \\
\text { foundation } 30-40 \text { m) }\end{array}$ & & \\
\hline Contingencies & $0.1 \%$ of the total budget \\
\hline Project Development \& Permits & $3.5 \%$ of the total budget \\
\hline Transportation (W/T \& Electrical Grid) & $0.1 \%$ of the total budget \\
\hline
\end{tabular}

TABLE VI. O\&M COSTS BREAKDOWN

\begin{tabular}{|c|c|c|c|}
\hline \multirow{2}{*}{\multicolumn{2}{|c|}{$\begin{array}{l}\text { Investment Factors } \\
\text { (Scenario A) }\end{array}$}} & \multicolumn{2}{|c|}{ Wind Offshore Site } \\
\hline & & \multirow{2}{*}{$\begin{array}{r}\text { Lemnos } \\
900,018,715.6\end{array}$} & \multirow{2}{*}{$\begin{array}{r}\text { Agios Efstratios } \\
177,515,556.5\end{array}$} \\
\hline NPV & $(€)$ & & \\
\hline IRR & $(\%)$ & 12.32 & 5.89 \\
\hline LCOE & $(€ / \mathrm{MWh})$ & 171.92 & 275.81 \\
\hline
\end{tabular}

\begin{tabular}{|l|l|l|}
\hline \multirow{2}{*}{ Annual Expenses } & \multicolumn{2}{|c|}{ Costs } \\
\cline { 2 - 3 } & \multicolumn{1}{|c|}{ Value } & \multicolumn{1}{c|}{ Rate } \\
\hline O\&M W/T & 2 & $\% /$ year \\
\hline O\&M Interconnection & 1.5 & $\% /$ year \\
\hline Asset \& Loss of Income Insurance & 0.25 & $\% /$ year \\
\hline Compensation to the local community & 3 & $\% /$ year \\
\hline Administration \& Security & $\approx 8,000$ & $€ / \mathrm{MW} /$ year \\
\hline
\end{tabular}

TABLE VII. INVESTMENT INDICATORS FOR SCENARIO A

\section{Results}

The results for the three projects applying the base case, scenario A, in TABLE VII show relatively higher LCOE costs compared to other wind offshore farms located in Europe (160-230 $€ / \mathrm{MWh}$ ) [29], due to the immaturity of wind offshore technology in Greece and lack of infrastructure. Agios Efstratios site, according to Scenario A records the lowest rate of return due to the wind energy output and high interconnection costs. Investment indicators show higher values for Lemnos offshore farm attributed to the higher capacity factor $\mathrm{C}_{\mathrm{f}}$.

\section{Sensitivity Analysis}

A sensitivity analysis has been applied using various scenarios in order to evaluate the performance of Lemnos and Agios Efstratios sites.

a) Scenario $A$ is the base case with independent transmission cables.

b) Scenario $B$ assumes the replacement of the two $2 * 250 \mathrm{MW}$ DC cables with a single $500 \mathrm{MW}$ link for both sites.

c) Scenario $C$ assumes the interconnection of the two wind farms Agios Efstratios and Lemnos with a DC link, and their common transmission through a 1000 MW DC link.

d) Scenario $D$ assumes the interconnection of Lemnos and Agios Eftstratios through an auxiliary AC link and their common transmission through 1) $2 * 500$ MW DC links in order to increase the reliability of the system or 2) one 1000 MW DC link.

e) Scenario $E$ assumes that the interconnection of the two wind farms takes place following the interconnection of the northern islands with Northern Greece.

f) Scenario $F$ is applied only to Agios Efstratios wind farm and assumes the replacement of the $5 \mathrm{MW}$ $\mathrm{W} / \mathrm{T}$ in with a DFIG $6.15 \mathrm{~W} / \mathrm{T}$.

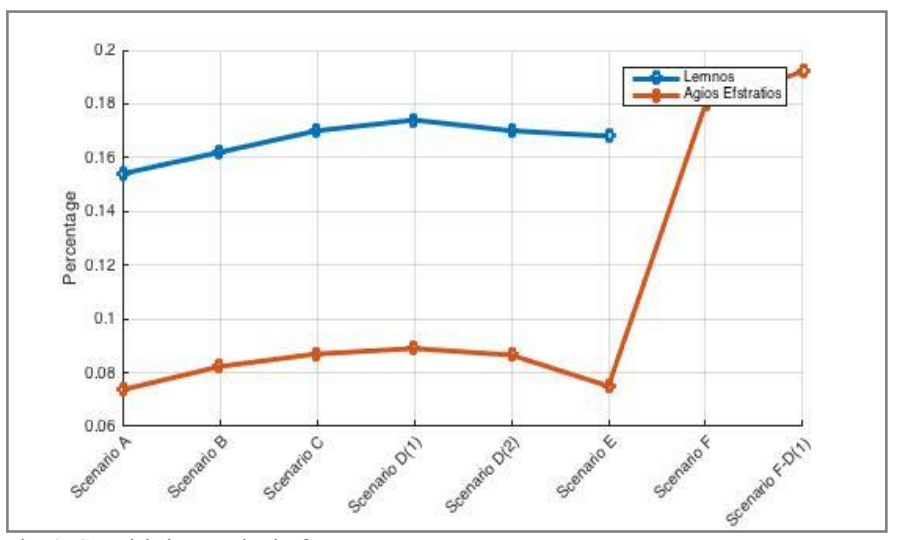

Fig.4. Sensitivity analysis for IRR

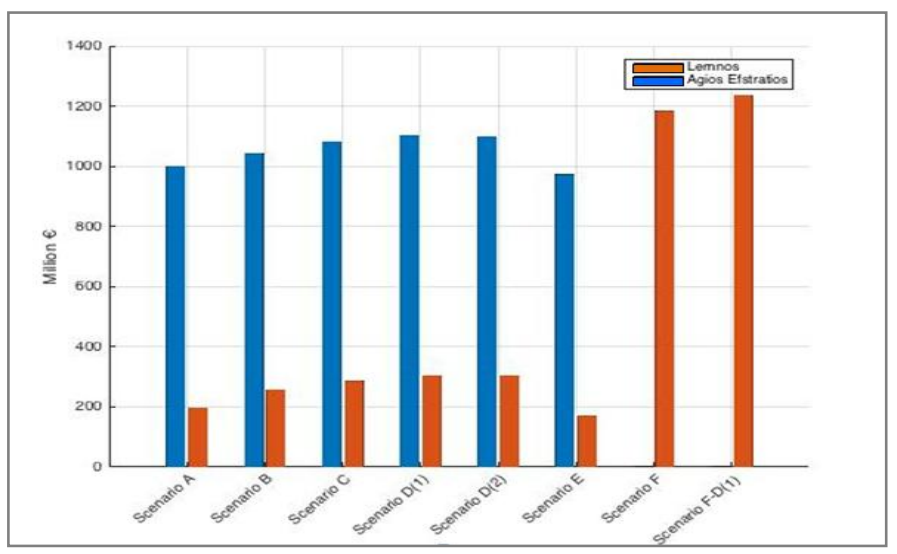

Fig. 5. Sensitivity for NPV 


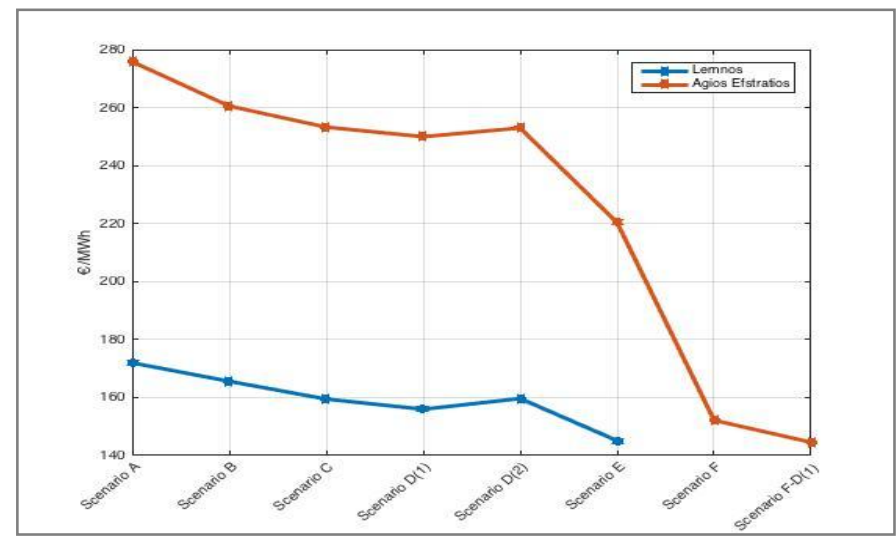

Fig. 6. Sensitivity Analysis for LCOE

It is evident that the concept of common transmission lines increases the investment profitability of wind offshore projects. However, it is recommended to opt for an option with two common 500 MW DC cables, instead of a common transmission line with $1000 \mathrm{MW}$, since it puts the power supply system under threat without securing the N-1 criterion. The optimization in Agios Efstratios investment case is obtained by applying Scenarios F and D1 together, while increasing the IRR factor to $19.2 \%$ (160\% growth) and NPV growth more than 5 times; respectively LCOE is reduced to $144.5 € / \mathrm{MWh}$. Regarding Lemnos, Scenario D1 demonstrates the optimum case with an increased IRR of $17.4 \%, 10.2 \%$ NPV increase and LCOE decrease to $155.9 € / \mathrm{MWh}$.

\section{CONCLUSIONS}

This study assesses the wind offshore potential of two sites located in the Aegean Sea. The technical specifications of the projects are presented and their economic feasibility is evaluated among different interconnection scenarios. The results show a high wind potential, leading to $\mathrm{C}_{\mathrm{f}}$ ranging between $44.7 \%$ and $46.8 \%$. Investment indicators showed that synergies in the interconnection of the wind offshore to the shore could increase significantly the profitability of the projects.

\section{REFERENCES}

[1] J. K. Kaldellis and M. Kapsali, "Shifting towards offshore wind energy-Recent activity and future development," Energy Policy, vol. 53, pp. 136-148, 2013.

[2] GWEC, "Global Wind Report annual market update, 2014Navigating the global wind power market," 2014.

[3] EWEA, "The European offshore wind industry key 2015 trends and statistics," 2015.

[4] GWEC, "Global Offshore: Current Status and Future Prospects," 2012. [Online]. Available: http://www.gwec.net/global-offshorecurrent-status-future-prospects/.

[5] A. Arapogianni, A.-B. Genachte, R. M. Ochagavia, J. Pascual Vergara, D. Castell, A. Rodriguez Tsouroukdissian, J. Korbijn, N. C. F. Bolleman, F. J. Huera-Huarte, S. Frieder, A. Ugarte, J. Sandberg, V. de Laleu, J. Maciel, A. Tunbjer, R. Roth, P. Coulombeau, P. de la Gueriviere, S. Jedrec, C. Philippe, S. Voutsinas, A. Weinstein, L. Vita, E. Byklum, W. L. Hurley, and H. Grubel, "Deep water-The next step for offshore wind energy a report, EWEA," 2013.

[6] Regulatory Authority for Energy, "Geospatial map for energy units and requests," 2014. [Online]. Available: http://www.rae.gr/geo/index.php?lang=EN.

[7] European Commission, "The 2020 climate and energy package," 2009. [Online]. Available: http://ec.europa.eu/clima/policies/package/index_en.htm [Accessed: 26-Mar-2015].

[8] S. Muller, M. Deicke, and R. W. De Doncker, "Doubly Fed Induction Generator Systems," IEEE Indusry Appl., pp. 26-33, 2002.

[9] A. Abo-khalil, D. Lee, and S. Lee, "Grid Connection of Doubly-Fed Induction Generators in Wind Energy Conversion System," 2006 5th Int. Power Electron. Motion Control Conf., no. 1, pp. 1-5, 2006.

[10] J. Fletcher and J. Yang, "Introduction to Doubly-Fed Induction Generator for Wind Power Applications," Paths to Sustain. Energy, pp. 259-278, 2010.

[11] P. Higgins and A. Foley, "The evolution of offshore wind power in the united kingdom," Renew. Sustain. Energy Rev., vol. 37, pp. 599$612,2014$.

[12] M. Bilgili, A. Yasar, and E. Simsek, "Offshore wind power development in Europe and its comparison with onshore counterpart," Renew. Sustain. Energy Rev., vol. 15, no. 2, pp. 905915, 2011.

[13] M. A. Lackner and M. A. Rotea, "Structural control of floating wind turbines," Mechatronics, vol. 21, no. 4, pp. 704-719, 2011.

[14] A. Reidy and R. Watson, "Comparison of VSC based HVDC and HVAC interconnections to a large offshore wind farm," IEEE Power Eng. Soc. Gen. Meet. 2005, no. 1, pp. 1-8, 2005.

[15] ABB, "Why HVDC? ABB DC systems products guide section." [Online]. Available: www.abb.com. [Accessed: 12-Dec-2015].

[16] J. P. Daniel, S. Liu, E. Ibanez, K. Pennock, G. Reed, and S. Hanes, "National Offshore Wind Energy Grid Interconnection Study Final Technical Report," p. 243, 2014.

[17] Entsoe, "Offshore Transmission Technology," Brussels, 2012.

[18] Z. Gaji, "HV Shunt Reactor Secrets," West. Prot. Relaying Conf., 2003.

[19] D. J. N. Strachan, "Offshore wind farm with centralised power conversion and DC interconnection," vol. 3, no. August 2008, pp. 586-595, 2009.

[20] P. Bresesti, W. L. Kling, R. L. Hendriks, and R. Vailati, "HVDC Connection of Offshore Wind Farms to the Transmission System," vol. 22, no. 1, pp. 37-43, 2007.

[21] S. I. Nanou, S. A. Papathanassiou, and M. P. Papadopoulos, "HV Transmission Technologies for the Interconnection of the Aegean Sea Islands and Offshore Wind Farms," 2015, no. November 2014.

[22] L. Xu, S. Member, L. Yao, and C. Sasse, "farms using VSC transmission. IEEE Trans Grid Integration of Large DFIG-Based Wind Farms Using VSC Transmission," no. March 2016, 2007.

[23] National Oceanic and Atmospheric Administration, "National Centers for Environmental Information, Bathymetry and Global Relief," 2014. [Online]. Available: https://www.ngdc.noaa.gov/mgg/bathymetry/relief.html. [Accessed: 01-Apr-2016].

[24] Communication Systems, National Technical University of Athens, CNR/ISMAR, THETIS, SEMANTIC, and METEO France, Wind and Wave Atlas of the Mediterranean Sea. Western European Armanents Organization Research Cell, 2004.

[25] M. Ragheb, "Wind Shear , Roughness Classes and Turbine," Production, 2015. [Online]. Available: http://mragheb.com/NPRE 475 Wind Power Systems/Wind Shear Roughness Classes and Turbine Energy Production.pdf. [Accessed: 23-Mar-2016].

[26] M. Ragheb, "Wind Energy Conversion Theory , Betz Equation," 2014.

[27] Enerdata, "Household-Electricity-Use."

[28] M. Junginger, "Learning in renewable energy technology development," Utrecht University, 2005.

[29] IEA, "IEA Wind Task 26," Wind Energy, pp. 1-122, 2011.

[30] Hellenic Republic, Law 4172 Income tax rate, direct measures of implementation for laws 4046/2012, 4093/2012 and 4127/2013. Greece, 2013.

[31] Hellenic Republic, Law 4254-Measures for the support and development of Greek economy in the framework of applying $L$. 4046/2012. Greece, 2014.

[32] ACER, "Report on unit investment cost indicators and corresponding reference values for electricity and gas infrastructure," no. August, pp. 1-17, 2015.

[33] E. Rosenauer, "Investment Costs of Offshore Wind Turbines," 2014 . 